\title{
Development of Connecting Extending Review (CER) Learning Model to Improve Student's Mathematical Reasoning Ability
} \author{
Iqbal Akbar Asfar ${ }^{4}$, Andi Nurannisa ${ }^{5}$ \\ ${ }^{1}$ Department of Educational Science, Universitas Negeri Makassar \\ Makassar, South Sulawesi, Indonesia \\ Email: tauvanlewisOO [AT] gmail.com \\ ${ }^{2}$ Department of Educational Science, Universitas Negeri Makassar \\ Makassar, South Sulawesi, Indonesia \\ Email: arifin_unm [AT] yahoo.co.id \\ ${ }^{3}$ Department of Engineering, Universitas Negeri Makassar \\ Makassar, South Sulawesi, Indonesia \\ Email: hamsuabdulgani [AT] unm.ac.id \\ ${ }^{4}$ Politeknik Negeri Ujung Pandang \\ Makassar, South Sulawesi, Indonesia \\ Email: andiifalasfar [AT] gmail.com \\ ${ }^{5}$ Universitas Muhammadiyah Bone \\ Bone, South Sulawesi, Indonesia \\ Email: andinurannisa30 [AT] gmail.com
}

Andi Muhammad Irfan Taufan Asfar ${ }^{1}$, Muhammad Arifin Ahmad², Hamsu Abdul Gani ${ }^{3}$, Andi Muhamad

\begin{abstract}
This study is a research \& development, a learning model of connection, extending, review (CER). The steps in this study consist of three steps, those are: (1) preliminary study including literature study, field study and initial product draf aranging; (2) testing with limited testing and broad testing; and (3) product testing through experiment. The analysis result shows that (a) validation step conducted by expert yield expert conclusion that developed CER learning model is generally good and in term of overall model and its learning instrument used (b) in step of model practicality it was obtained the overall achievement of practicality aspec that it has fulfill the criteria of very practical; (c) limited test shows analysis result with the effect size on the category of significant effect with improvement mostly in high category. Broad testing with two times of testing in two student groups, shows the effect size of in significant effect category. (3) Product testing through experimental study shows that there was a significant score of students' mathematical reasoning of experimental group after the implementation of CER learning model with the effect size of category as (0.910) compare to control group with the medium effect size as (0.664).
\end{abstract}

Keywords--- connection, extending, review, Matematical reasoning

\section{INTRODUCTION}

Mathematics is one of the basic sciences that humans learn from various levels of education and ages [1] where the process can train students in analytical thinking and logic [2] [3]. Although mathematics has an important role in life, in reality, Indonesian students on average only master the first cognitive domain, namely knowledge and have not yet reached the level of application and reasoning [4] [5]. This fact is in line with the results of the 2015 TIMSS survey which showed Indonesia was ranked 46th out of 51 countries with an average of 397 [6]. This result is not significantly different from the results of the PISA study in 2018 where Indonesia ranks 73 out of 79 countries with a score of 379 out of an average score of 490 [7]. One of the components of the questions tested in TIMSS is the cognitive domain at the level of reasoning. At this level, many students experience errors in completing the test. Therefore, the information obtained from PISA and TIMMS can be used as a reference for educators in training students' reasoning abilities in each educational unit. Students who have mathematical reasoning abilities will find it easy to examine a problem so that they better understand the concept of the subject matter itself, not just rote [8]. 
Reasoning can be interpreted as a series of mental processes used to obtain conclusions. Students who are explicitly taught reasoning and discovery strategies will more easily transfer and connect their thoughts with new reasoning [9] [10] and can increase future job opportunities [11]. Reasoning is closely correlated with mathematical ability [12] [13] [14] thus enabling students, including teachers, to understand mathematics and actively build mathematical ideas with collaborative exchange of ideas (Hwang, Choi \& Hand, 2020). Mathematical reasoning ability is the ability to solve a problem which includes the ability to construct conjectures, perform analogy processes, prove, and analyze or estimate the answers to problems based on known patterns or elements [15] [16].

From the results of observations of class XII students in several high schools in Bone Regency, it shows that the reasoning abilities of students are poor, in which students tend to lack organizing skills to solve problems, lack of students' ability to communicate ideas in solving mathematical problems so that students tend to be confused in solving problems in using a concept or formula. This causes teachers to be more active than students. One of the factors causing this problem is because teachers still use several less effective learning models in delivering learning materials and exploring students and the lack of stimulating students to actively build their own knowledge. Besides that, the lack of giving questions that relate to contextual problems so that students' reasoning power is not trained which results in reduced interest in learning mathematics. This is in line with what was stated by [17] that the factor causing the low reasoning of students was because the questions given by the teacher emphasized more on understanding concepts while questions that required higher-order thinking skills, including mathematical reasoning, were rarely trained.

To overcome the problems, the researchers developed a Connecting, Extending, Review (CER) learning model where the stages are in accordance with the process of thinking activities through a reasoning process consisting of sense-making, conjecturing, convincing, reflecting and generalizing. (1) Sense-making is closely related to the ability to build problem scheme and represent the knowledge possessed. When understanding a mathematical situation and then trying to communicate it into symbols or mathematical language, at that time a sense-making process occurs through the process of adapting and linking newly acquired information with previous knowledge so as to form new information that is interconnected in the structure of knowledge, this is in accordance with connecting stages, (2) Conjecturing and convincing, conjecturing means the activity of predicting a conclusion, and theories based on incomplete facts, and the product of the conjecturing process is a solution strategy. Convincing means doing or implementing a settlement strategy based on the two previous processes. These two stages are in accordance with the provision of various questions at the stages (extending), (3) Reflecting and generalizing, reflecting is an activity to re-evaluate the three processes that have been carried out by reviewing their relationship with theories that are considered relevant. Generalizing means that the final conclusions obtained from the whole process are then identified and generalized in a process. The reflecting and generalizing stages correspond to the reviewing stage.

\section{METHOD}

This study is a type of research and development with the aim of developing a learning model, namely the Connection, Extending, Review (CER) learning model. The development research model used is the result of a modified Borg and Gall development model with the aim of developing and testing products [18]. The steps in this research consist of three steps, namely: (1) preliminary study which includes literature study, field study and preparation of the initial draft of the product; (2) a testing with a limited sample (limited testing) and a wider sample trial (broad testing); and (3) product testing through experiments. Visually it can be seen in Figure 1.

The selection of locations for limited trials, extensive trials and experimentation tests was based on data on the number of study group classes, as well as the readiness of teachers who were the samples of this research and development. The limited trial will be conducted at SMAN 19 Bone and the location for the extensive trial is planned to be carried out at SMAN 11 Bone. The experimental implementation of the learning model will be carried out at SMAN 6 Bone. The research instruments used in this study were observation, interviews, written tests, and documentation. Meanwhile, the data analysis was adjusted to the data collected, some were analyzed descriptively qualitatively, and some were analyzed quantitatively using inferential statistics. 


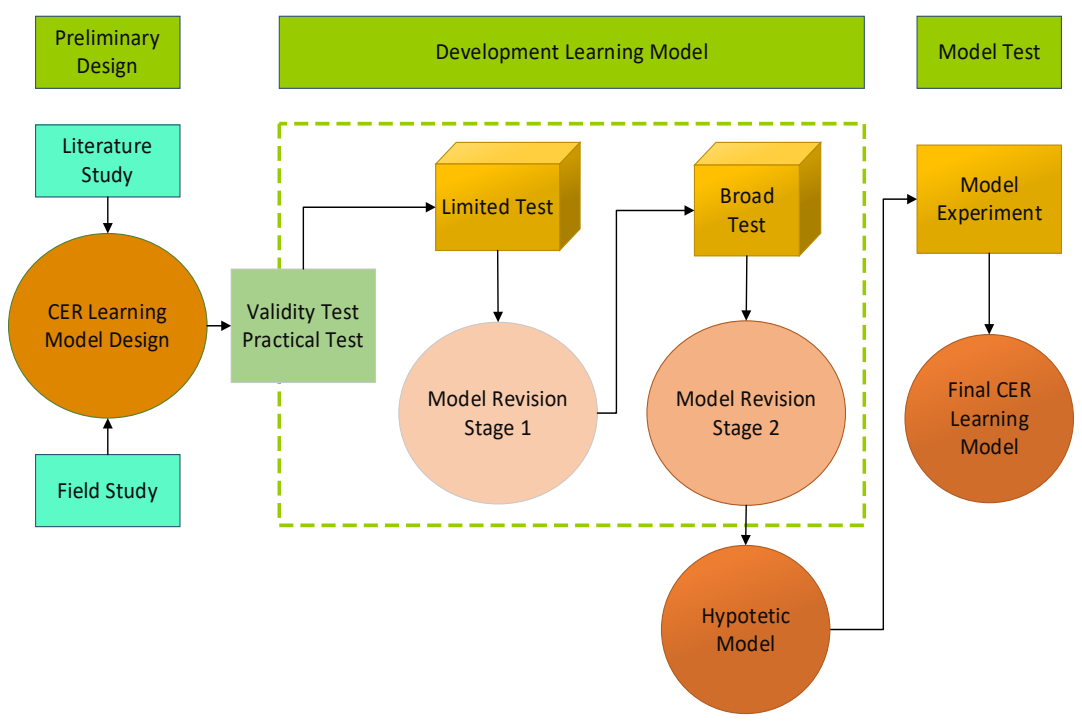

Figure 1. Research Steps for CER Learning Model Development

For the implementation of the learning model, the data to be processed are learning outcomes tests and attitude scales to determine the ability of mathematical reasoning and student attitudes in learning. Learning outcomes test is used to measure the extent to which students understand the material being studied, as well as students' mathematical reasoning abilities. This test is in the form of a written test in the form of an essay with 5 questions which is carried out twice, namely a test before and after applying the learning model which is done by individual students. The indicators used are simplified into an easier form in calculating students' mathematical reasoning results, including the following [19] [20].

Table 1. Indicators of Mathematical Reasoning

\begin{tabular}{cc} 
Mathematical reasoning indicators & Mathematical reasoning aspec \\
\hline $\begin{array}{c}\text { Present mathematical question in a form of } \\
\text { written, figure, and diagram }\end{array}$ & $\begin{array}{c}\text { Students show a very good understanding of assuming something that is } \\
\text { known or asked so that they are able to convert problems into mathematical } \\
\text { form appropriately so that they are able to present mathematical statements } \\
\text { either in writing, pictures, or diagrams and perform calculations.. }\end{array}$ \\
\hline $\begin{array}{c}\text { Submit a conjecture } \\
\text { reasons or evidence for some solutions }\end{array}$ & $\begin{array}{c}\text { Students can propose alleged answers, determine patterns and can perform } \\
\text { mathematical manipulations in solving problems logically, precisely and } \\
\text { systematically. }\end{array}$ \\
\hline & the results that have been obtained, then conclude the results of problem \\
solving accurately and logically.
\end{tabular}

\section{RESULT AND DISCUSSION}

The learning model developed consists of three stages of learning according to the syllable aspect, namely the Connecting, Extending, and Review stages. (1) Connecting in language means come or bring together, so connecting can be interpreted by connecting. At this stage students are grouped so that interaction occurs between students in issuing ideas or ideas in solving mathematical problems so that there is an inter-connection of knowledge among group members; (2) Extending is defined as expanding/developing, which means expanding or developing the knowledge that has been learned and then applying it to further problems, namely similar questions with varying levels of difficulty; (3) Review is the stage where students repeat the material learned, and focus on the questions given by the teacher and students ask if they are still not sure of their understanding of the material.

\subsection{The Learning Theory as the Basis of CER Learning Model}

The learning theory that underlies the modification of the learning model is cognitive learning theory. The reason for the learning theory that underlies the modification of the learning model is that if you look at the characteristics of cognitive learning theory, namely insight depending on past experience that is relevant (with what is learned), this is the same as the first step of the learning model, namely Connecting. Learning with insight can be repeated, meaning that problem solutions using insight can be repeated easily and will apply on an ongoing basis, this is the same with review activities. Another reason for cognitive learning theory is that active student involvement in learning is very important, because only by 
activating students can the process of assimilation and accommodation of knowledge and experience occur properly, this means that cooperation is important in learning. Besides, collaborating makes the process of knowledge transfer easier, especially by giving various questions (Extending). Giving a variety of questions to students is expected that students will be able to answer math problems given, especially questions in the form of reasoning.

\subsection{Social System}

The social system in a learning model is the interaction that occurs between learning actors. Learning using the CER learning model is student-centered, where the teacher acts as a facilitator and moderator. As a facilitator, the teacher provides learning resources, encourages students to learn by involving the senses and intellectually by connecting knowledge and material to be studied, providing assistance to students in order to learn and construct knowledge optimally, and provide feedback on what has been learned. As a moderator, the teacher creates a condition where students can argue and cooperate in learning through group discussions using teaching aids.

\subsection{Reaction System}

Teacher Role:

a) The teacher motivates students by providing examples related to the material to be studied.

b) The teacher connects students' knowledge with the material to be delivered.

c) The teacher gives an assessment in groups.

d) The teacher provides individual exercises with a variety of questions.

Student Role:

a) Students connect their knowledge with the material to be delivered.

b) In groups, students work together with their group friends in solving problems.

\subsection{Support System}

The support system related to the syntax in the CER learning model includes all the facilities, materials and tools needed to support the implementation of the learning model. Learning media includes physical tools used to deliver the contents of teaching materials consisting of books, LCDs, teaching aids and laptops and smartphones. The CER learning model uses presentation media in the form of powerpoints, modules and worksheets, specifically online learning using additional applications such as Zoom, Meistertask, Mindmeister, and Liveworksheets.

\subsection{Instructional Effect and Nurturant effect}

The instructional effect and nurturant effect generated after the application of the CER learning model can be seen in the figure below.

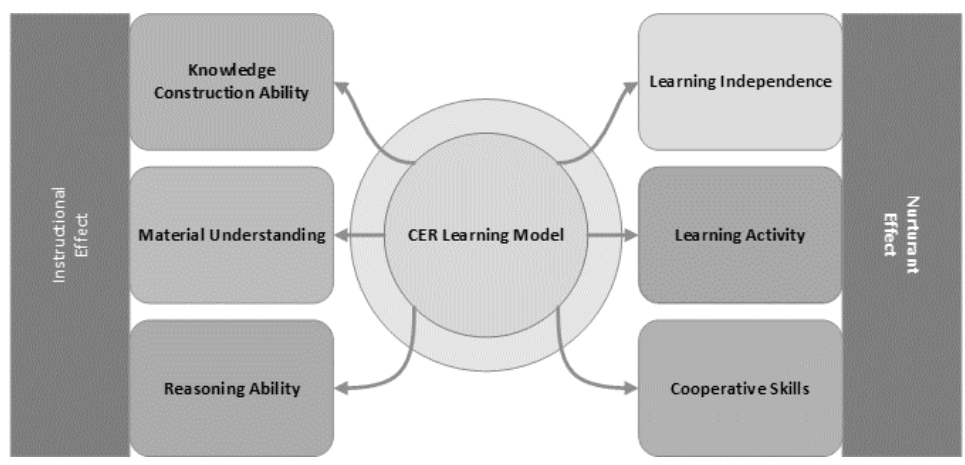

Figure 2. Impact of CER Learning Model Accompaniment

The results of the validation of the CER learning model by two experts (validator experts) with three mathematics subject teachers as users showed an average validation of the learning components with an average score of 9.75 (very valid category) for expert validators and 9.92 (very valid category) for the user validator. The results of the RPP validation obtained an average score of 90 (very valid category) for expert validators and 90.3 (very valid category) for user validators. For the material (modules) used in the study, the score was 116 (very valid category) for expert validator and 131 (very valid category) for user validator. Meanwhile, the results of LKPD validation obtained a score of 63 (very valid category) for expert validator and 63.3 (very valid category) for user validator. As for the results of the validation of the reasoning test instrument mathematics reaches a percentage of $100 \%$ until it is declared feasible to use. The results of the practicality of the CER learning model based on teacher and student assessments have been declared practical to use, namely getting a percentage of $100 \%$ of the teacher's response and $79 \%$ of the student's response. Based on the practicality assessment 
criteria, the teacher's response and students are in very practical category.

The results of the analysis of the effectiveness of the CER learning model show that overall it has been maximized and carried out well / smoothly according to the researcher's plan. The following is a description of the results of the effectiveness test in the application of the CER learning model in the field to improve students' mathematical reasoning abilities.

\subsection{Mathematical Reasoning Ability}

The students' mathematical reasoning ability on the research results can be seen from the average score obtained as a whole. The improvement that occurs with the application of the CER learning model can be compared from the results of each model trial and comparison with the control class. This is fully explained in the following discussion.

\section{Average Mathematical Reasoning Ability}

Learning by using the CER learning model can improve students' mathematical reasoning abilities is considered from the increase in the average score for each learning implementation trial obtained by students in the experimental group during the learning process. In this learning, students are motivated to learn with various real concept approaches given. This is in line with the research of [21], where students are motivated to find out and think to solve a given problem with a conceptual approach that is connected to the student's initial concept [22]. The CER learning model also emphasizes the concept approach which according to Dewi \& Agustika (2020) is able to train students' reasoning skills in solving mathematical problems. Learning outcomes using the CER learning model are in the form of increasing mathematical reasoning abilities as measured by mathematical reasoning indicators, namely (1) presenting mathematical statements orally, in writing, pictures and diagrams, (2) proposing conjectures (3) drawing conclusions, compiling evidence, providing reasons or evidence against some solution. An overview of the results of the application of the CER learning model at SMAN 19 Bone, SMAN 11 Bone and SMAN 6 Bone can be seen through the bar chart in Figure 3.

Based on the bar chart in Figure 3, it shows that the results of the application of the CER learning model at the limited test stage obtained an average student posttest score of 87.64. Although the posttest results of students are in the high category, the process of implementing the CER learning model is still not optimal due to several factors, namely student readiness in learning, implementation time, the sample used by the randomized method from the three classes so that it affects students' cooperative attitudes in learning. This becomes a reference for the revision of the learning model starting from the learning syntax to the question instruments and LKPD used. After the results of the revision it was then proceed to the wider testing phase of the model.

In the broad test stage there was an increase in the score of students' mathematical reasoning results by 88.75 in posttest 1 and an average score of 90 in posttest 2, this shows that the revised results provide an increase in the average score of students' mathematical reasoning abilities. In the model validation test stage, the pretest mathematical reasoning ability score was 52.64, an increase after the application of the CER learning model was 95.83. These results indicate that the CER learning model has an effect on improving students' mathematical reasoning abilities.

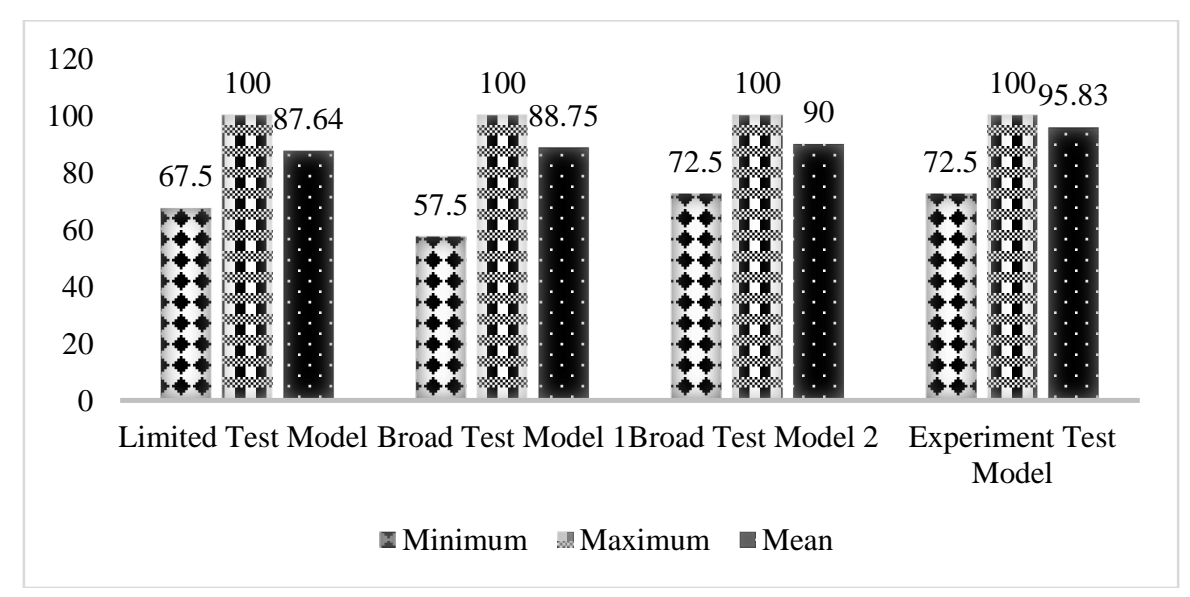

Figure 3. Bar Chart Comparison of the Results score of the Implementation of the CER Learning Model

The results of increasing students' mathematical reasoning ability scores are strengthened by the results of the analysis of the average increase in students' mathematical reasoning and the effective contribution of the application of the CER learning model which can be seen through the bar chart in Figure 4. 


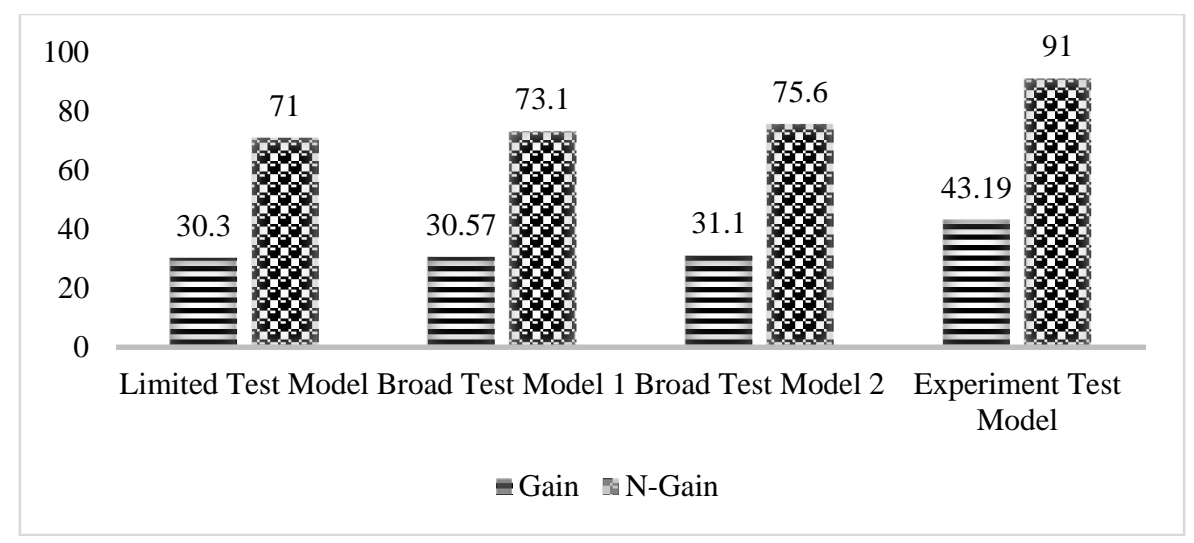

Figure 4. Bar Chart Comparison of Gain and N-Gain of the CER Learning Model

Based on the data above, it appears that there was an increase in students' mathematical reasoning abilities from the limited model test, model area test and model validation test, the average score increased from 30.3 and the n-gain was in the high category $(71 \%)$. In the broad test model 1 of 30.57 and the n-gain in the high category $(73.1 \%)$ then increased to 31.1 and the n-gain in the high category $(75.6 \%)$ in the broad test model 2. Furthermore, there was a significant increase in the the model validation test is 43.19 with $n$-gain in the high category $(91 \%)$. In the effective contribution (effect size) of the CER learning model is in the large effect category where in the limited test the effect size model is 2.91 then 2.81 in the model 1 area test stage and 2.628 in the 2 model area test. Effect size has increased significantly on the model product validation test of 4.48. This shows that the application of the CER learning model has a consistent impact on students' mathematical reasoning abilities.

\section{Differences in Mathematical Reasoning Ability in Control Class and Experiment Class}

Based on the results of the analysis showed the control class with an average score of students' mathematical reasoning ability on the pretest of 56.5 and an increase in the posttest measurement of 78.54 or an increase of 21.94 points with the average mathematical reasoning of students included in the good category. In the experimental class the average score of students' mathematical reasoning abilities was 52.64 and there was an increase in the average score in the posttest final measurement of 95.83 or an increase of 43.19 points with the average mathematical reasoning of students in very good category. This is also proven in the N-gain test, the results of the increase in the experimental class after the application of the CER learning model are included in the high category of $91 \%$, while the control class with the application of the problem-based learning model (PBL) is in the medium category of 50.5\%. There appears to be an increase in students mathematical reasoning in both the control class and the experimental class, but the students' mathematical reasoning ability in the control class is lower than the experimental class. This result is reinforced by the analysis of the Mann-Whitney test on the posttest $U$ value of $65.5(p=0.002)$ which shows $p<0.05$, meaning that there is a difference in the average score of the control class and the experimental class.

The increase in students' mathematical reasoning abilities in the control class that has not been maximized can be caused by the lack of students' ability to analyze existing problems. Students only focus on the results without paying attention to the procedures they go through to achieve the final result of a problem solving. According to [23]the PBL learning model can improve students' reasoning abilities in solving mathematical problems, but has not been able to thoroughly explain the procedures it goes through in achieving these final results. Whereas understanding, analyzing, and being able to work is a single unit in terms of developing thinking skills, especially reasoning [24]. Meanwhile, the CER learning model applied to the experimental class trains students in analyzing each problem to achieve final results through the stages of connecting, extending and reviewing, so that students can easily explain what they get with reasonable reasons, so that they don't only understand conceptually the material but at the same time they are also taught that they are also able to explain the procedure of solving the given problem. One of the activities that can be done to obtain the maximum learning process, namely educators are required to be able to encourage students to be actively involved, especially in terms of discussion, ask and then answer questions, think critically, then explain each answer given, and give reasons for each answer. Proposed [25]. Therefore, the developed CER learning model is effective in improving students' mathematical reasoning abilities and is better than the PBL learning model.

The success of the CER learning model is supported by positive teacher and student responses. This can be seen from the four indicators consisting of management, activity, knowledge and effectiveness. The four indicators show that students attitudes towards learning with the CER learning model are positive, this can also be seen from the average score of the four indicators, which is 3.87 . The existence of a positive attitude in the learning process will be closely related to the achievement of mathematics learning in improving mental and experiential constructivist so that students do not understand 
procedurally but also conceptually [24]. The positive response given by teachers and students to the application of the CER learning model can be used as an alternative solution to support successful learning in improving students' mathematical reasoning abilities. This can also have implications for students' motivation and learning achievement.

\section{CONCLUSION}

Based on the results and discussion of the study, it can be concluded that the developed CER learning model has met the valid and practical criteria based on the validation results of two experts (validator experts) and three mathematics subject teachers as model users. In the model effectiveness test, it shows that the CER learning model is effective in improving students' mathematical reasoning abilities as seen from the increase in student learning outcomes in each test, which were an increase of $71 \%$ in the first test, $73.1 \%$ in the second test, $75.6 \%$ in the third test and increased significantly in the fourth test by reaching a percentage of $91 \%$. Besides increasing students' mathematical reasoning abilities, the CER learning model is also able to improve students' collaboration skills in the learning process, communication skills from group discussion processes, and able to increase students' motivation to learn mathematics. This can be seen in the positive student responses to the application of the CER learning model developed with a practicality percentage of $79 \%$. Student responses to learning are positive, because most students are interested, serious and motivate them to learn, students agree that learning makes it easier for them to interact more by way of discussion between students and teachers, makes them ask more questions and share knowledge, and the CER learning model makes them concentrate more in understanding the subject matter, increase student knowledge and be able to answer questions and questions given.

\section{REFERENCES}

Agustin, D., Syahbana, A., \& Paradesa, R. (2018). Pengaruh Metode Mind Mapping terhadap Kemampuan Pemahaman Konsep Matematis dan Motivasi Belajar Siswa SMP Negeri 5 Prabumulih. Jurnal Pendidikan Matematika RAFA, 4(1), 9-18.

Agustin, S.S., Purwanto, S.E., Ma'arif, S. \& Soebagyo, J. 2020. Analisis Kemampuan Penalaran Matematis Peserta Didik dengan Penyajian Masalah Open-Ended Pada Pembelajaran Daring. Jurnal Riset HOTS Pendidikan Matematika. 1 (1): 66-80.

Asfar A M I T, Nur S and Asfar A M I A. 2019. The Improvement of Mathematical Problem-solving through the Application of Problem Posing \& Solving (PPS) Learning Model Proc. International Conference Advance Multidisiplinary Reserarch. (Amsterdam: Atlantis Press) pp 362-6

Asfar A, Asfar A, Asfar A H, Sirwanti, Rianti M and Kurnia A. 2019. The Elaboration Study as an Innovative Learning Model in an Effort to Improve the Understanding of Mathematics International Journal Innovation, Creativity Change. 5(3): 842-64

Asfar, A. M. I. T., Asfar, A. M. I. A., \& Nurannisa, A. (2021). Integration of Local Traditions Bugis-Makassarese: Learning Strategies to Improve Mathematical Communication Skills. In Journal of Physics: Conference Series (Vol. 1808, No. 1, p. 012064). IOP Publishing.

Astuti, E. Puji. 2017. Penalaran Matematis Dalam Menyelesaikan Masalah Matematika Siswa SMP. Jurnal Pendidikan Surya Edukasi (JPSE). 3 (2): 83-91.

Dewi, N. P. W. P., \& Agustika, G. N. S. (2020). Efektivitas Pembelajaran Matematika Melalui Pendekatan PMRI Terhadap Kompetensi Pengetahuan Matematika. Jurnal Penelitian dan Pengembangan Pendidikan, 4(2), 204-214.

Fadillah, A. 2019. Analisis Kemampuan Penalaran Deduktif Matematis Siswa. Jurnal Teori dan Aplikasi Matematika (JTAM), 3 (1): 15-21.

Hwang, J., Choi, K. M., \& Hand, B. (2020). Examining domain-general use of reasoning across science and mathematics through performance on standardized assessments. Canadian Journal of Science, Mathematics and Technology Education, 20(3), 521-537.

Kurino, Y.D. 2020. Model Problem Based Learning (PBL) pada Pelajaran Matematika di Sekolah Dasar. Jurnal Elementaria Edukasia. 3 (1): 150-154.

Lestari, S. I., \& Andriani, L. (2019). Pengaruh Penerapan Strategi Pembelajaran Scaffolding terhadap Kemampuan Pemahaman Konsep Matematis Siswa Madrasah Tsanawiyah Al-Hidayah Singingi Hilir ditinjau dari Motivasi Belajar Siswa. Suska Journal of Mathematics Education, 5(1), 68-76.

Lowrie, T., Resnick, I., Harris, D., \& Logan, T. 2020. In search of the mechanisms that enable transfer from spatial reasoning to mathematics understanding. Mathematics Education Research Journal, 32(2), 175-188.

Mullis, I. V. S., Martin, M. O., Foy, P., \& Hooper, M. (2016). TIMSS 2015 International Results in Mathematics. Retrieved from Boston College, TIMSS \& PIRLS International Study Center website: http://timssandpirls.bc.edu/timss2015/international-results/

Nasruddin, N., Mashuri, S. \& Nafiah, U. 2020. Peningkatan Hasil Belajar Matematika pada Materi Segitiga Melalui Pendekatan Penemuan Terbimbing Siswa SMP. Jurnal Penelitian dan Pengkajian Ilmu Pendidikan: e-Saintika. 4 (2). 80-94 
Nasution, R.S., Fauzi, K.M.A. \& Syahputra, E. 2020. Pengembangan Soal Matematika Model PISA pada Konten Space and Shape Untuk Mengukur Kemampuan Penalaran Matematis. Paradigma Jurnal Pendidikan Matematika. 13 (3). 1-10.

Noviana W., Suyono, Hakim, LE. 2018. Pengaruh Pendekatan M-APOS Terhadap Kemampuan Penalaran Matematis Siswa SMP Negeri di Kota Tangerang. Jurnal Riset Pendidikan Matematika Jakarta, 1 (1): 31 -38.

OECD. 2019. Programme for International Student Assesment (PISA) 2018 Result: Combined Executive Summaries, Volume I, II \& III. https://www.oecd.org/pisa/Combined_Executive_Summaries_PISA_2018.pdf.

Ontario Ministry of Education. 2014. Paying attention to Spatial ReaSoning. Toronto, ON: Queen's Printer for Ontario (Online), (http://www.edu.gov.on.ca/eng/literacynumeracy/LNSPayingAttention.pdf

Putri, D.K., Sulianto, J., Azizah, M. 2019. Kemampuan Penalaran Matematis Ditinjau dari Kemampuan Pemecahan Masalah. International Journal of Elementary Education, 3 (3): 351-357.

Saputri, I., Susanti, E., Aisyah, N. 2017. Kemampuan Penalaran Matematis Siswa Menggunakan Pendekatan Metaphorical Thinking Pada Materi Perbandingan Kelas VIII di SMPN 1 Indralaya Utara. Jurnal Elemen, 3 (1): 15-24.

Siregar, R.M., Mujib, A., Hasratuddin \& Karnasih, I. 2020. Peningkatan Kemampuan Berpikir Kreatif Siswa Melalui Pendekatan Matematika Realistik. Jurnal Pendidikan Edumaspul. 4 (1): 56-62

Sofyana, U. Mega, Kusuma, A. Badu. 2018. Upaya Meningkatkan Kemampuan Penalaran Matematis Siswa Menggunakan Pembelajaran Generative Pada Kelas VII SMP Muhammadiyah Kaliwiro. Jurnal Penelitian Didaktik Matematika, 2 (2): 11-23.

Suprihatin, T.R., Maya, R., Senjayawati, E. 2018. Analisis Kemampuan Penalaran Matematis Siswa SMP Pada Materi Segitiga dan Segiempat. Jurnal Kajian Pembelajaran Matematika, 2 (1): 9-13.

Suriani. 2020. Penerapan Model Open Ended Learning Untuk Meningkatkan Aktivitas dan Hasil Belajar Matematika pada Materi Operasi Hitung Bilangan Kelas IV MIN 1 Aceh Barat Daya. Jurnal Pendidikan dan Pengabdian Vokasi. $1(1): 107-116$

Sutrisno, J. 2020. Self-Regulated Learning: Intelligence Quotient and Mathematical Disposition. Journal of Physics: Conference Series. 1422: 1-7. 